\title{
Acculturation in the Architecture of Lasem City
}

\author{
L. M. F. Purwanto ${ }^{1, *}$, Yulita Titiek S. ${ }^{2}$ \\ ${ }^{1}$ Department of Architecture, Soegijapranata Catholic University Semarang \\ Semarang, Indonesia \\ ${ }^{2}$ Department of Architecture, Soegijapranata Catholic University Semarang \\ Semarang, Indonesia \\ *Corresponding author's email: Imf_purwanto [AT] unika.ac.id
}

\begin{abstract}
Lasem city, located on the northern coast of Java, is particularly well-known for its buildings with Chinese architecture, thus the nickname "Little Chinese (or China) in Java". Despite the deeply ingrained Chinese ethnicity in Lasem, history recorded the tight bond of solidarity between the Chinese and the Javanese. Religious, racial, and ethnic conflicts between the two ethnic groups hardly existed.
\end{abstract}

By using the phenomenological approach, this research focuses on the process of acculturation in Lasem. It specifically attempts to document the acculturation process manifested through building structures and settlement patterns as a model of the daily life of the Indonesian society.

The findings of the study suggested that acculturation process has greatly influenced the structure of the buildings in Lasem. Many buildings in Lasem mix the Chinese and Javanese architectures in their space layout and details. The outcome of this research is a model of acculturation process reflected in architecture. This model can be implemented in other cities in Indonesia.

Keywords - Lasem city, acculturation, local wisdom

\section{INTRODUCTION}

Lasem is a city with a particularly interesting history. Although small, Lasem save artifacts historically associated with the process of acculturation between Javanese and Chinese, and prove that a relationship of peace and harmony between Javanese and Chinese have been forged since centuries ago (Vlekke, 1959) Lasem is a town dominated by ethnic Chinese so that the city is often dubbed the "little China". However, such dominance has formed a harmony of mutual benefit and mutual need between the Javanese and the Chinese centuries ago (Rizali, N. \& Bani Sudardi, 2015). Interethnic acculturation in Indonesia has occurred as a result of the interaction between the various cultures of settlers or immigrants and local Javanese cultures with all their different characteristics and forms. (Widodo, S.T., 2015). The first Chinese immigrants arrived there in the thirteenth century, and later on they assimilated well with the local people. They had good synergy and later they even formed alliance to fight against the Dutch colony. The Chinese community assimilated with the local citizen through marriage and acculturation. This created a peaceful environment and strong unity and thus, problems in the community can be peacefully resolved. Lasem inhabitants were aware of how disadvantageous the conflicts would be for the community and themselves. In 1743-1745, three prominent figures became the role model of the acculturation process. They were Oey Ing Kiat, Tan Kee Wie, both were Chinese, and Raden Panji Margono. Together, they fought against the Dutch. Until now the city of Lasem has never experienced horizontal conflicts (Aziz, M., 2014).

The Chinese people in Indonesia arrived for the first time in Indonesia to trade. These Chinese merchants travelled to different parts of the archipelago. In 1405, a Muslim Admiral, Cheng Ho, from Ming Dynasty embarked for Indonesia and arrived at the main ports of Java that time such as Tuban, Rembang, and Lasem (Tan Ta Sen, 2010). Beside trading, the Chinese merchants also proselytized Islam. Chinese people indeed had greatly contributed to building of the nation in terms of agriculture, religion, and culture. Therefore it is suprising to see, later on, how local people viewed them cynically. In his book, Leo Suryadinata (1984) wrote about the sentiment towards Chinese people stated by Mayor General Soemitro in "Antara" newspaper on January 5 1967. Sumitro stated that the government no longer accepted temples, and all aspects of Chinese heritage, and cultures. They had to be replaced with Javanese culture. 
The New Order regime triggered many conflicts, but the city of Lasem remained unaffected. The city was able to maintain its culture and preserve its building ornaments without creating resentments or conflicts. The awareness of the importance of social harmony and peaceful society was the result of the course of history from the Dutch colonization until today (Aziz M. , 2014). In architecture, the process of acculturation is evident through details of the buildings and layouts of the Chinese and Javanese buildings.

\section{RESEARCH METHOD}

In this study, the researchers examined a house in Lasem that was influenced by acculturation. Chinese houses in Lasem have different space layouts in comparison with those in China. The assimilation and acculturation processes between the Chinese and the local people resulted in houses having layouts similar to those of Javanese houses. There are houses with Dutch architecture whose layouts are influenced by both Javanese and Chinese architectures. On the contrary, distinctive console forms found in many Javanese traditional houses in Lasem reflect the influence of the Chinese architecture.

In addition, this study investigated the cultural interactions in the society particularly those related to settlement patterns. The information regarding social lives in Lasem were collected from interviews with the prominent Javanese and Chinese local figures who were instrumental in the preservation of Lasem's cultural heritage. These people were the members of the Lembaga Kajian Sejarah Lasem (Center for Lasem Historical Studies).

\section{RESULTS AND DISCUSSIONS}

Chinese immigrants arrived in Lasem for the first time in the thirteenth century. The Chinese community was then settled and lived along the Lasem River which was their main transportation route in the $15^{\text {th }}$ century. . They first settled in Babagan. (Pratiwo, 2010). Their daily activities mostly revolved around managing salt farms and introducing salt making to the local people. Bie Nang Oen, whose name is now used as a place name in Lasem, Binangun, along with his wife $\mathrm{Na}$ Lie Nie was the first Chinese figures who taught the local people about agriculture, salt production, and crafting. Later on, more Chinese people from Hokkien clan arrived and settled in Soditan area. Their first dwellings were located near the Lasem port (Rahab, 2014).

In 1743-1745, Lasem was ruled by an Adipati (regent) named Raden Ngabehi Widyadinigrat, a muslim Chinese and a Dutch mayor. His real name was Oey Ing Kiat. He befriended the son of Lasem's previous regent (Tejakusuma V, 1714-1727), Raden Panji Margono, and also a kungfu master Tan Kee Wie. These three people were very close to each other and fought against the Dutch, especially the VOC (Vereenigde Oostindische Compagnie/Dutch East-Hindia Company) because of the mass killing of Chinese people in Batavia. This incident is known as Perang Kuning (Yellow War). They died a hero during this particular uprising. Their loyalty and dedication were commemorated in Gie Yong Bio temple, Babagan.

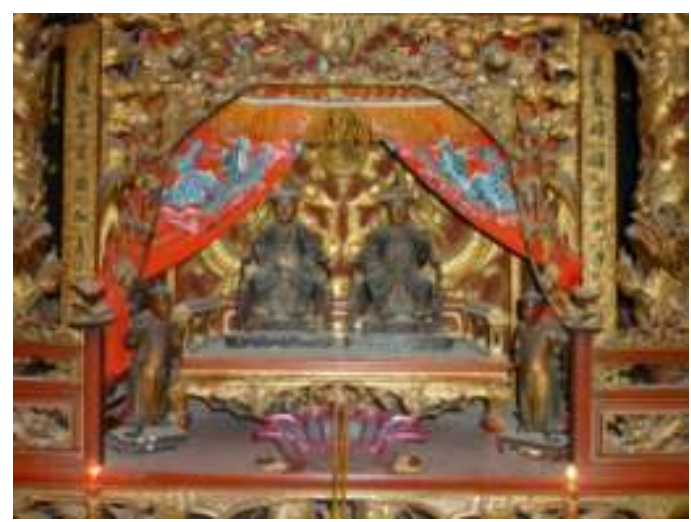

Figure 1 The aisle to honor Oey Ing Kiat and Tan Kee Wie in the Gie Yong Bio Temple 


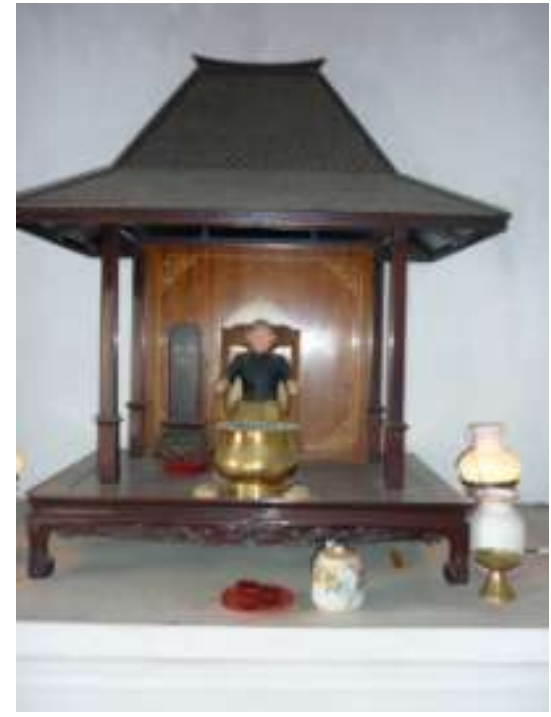

Figure 2 The aisle to honor Raden Panji Margono in the Gie Yong Bio Temple

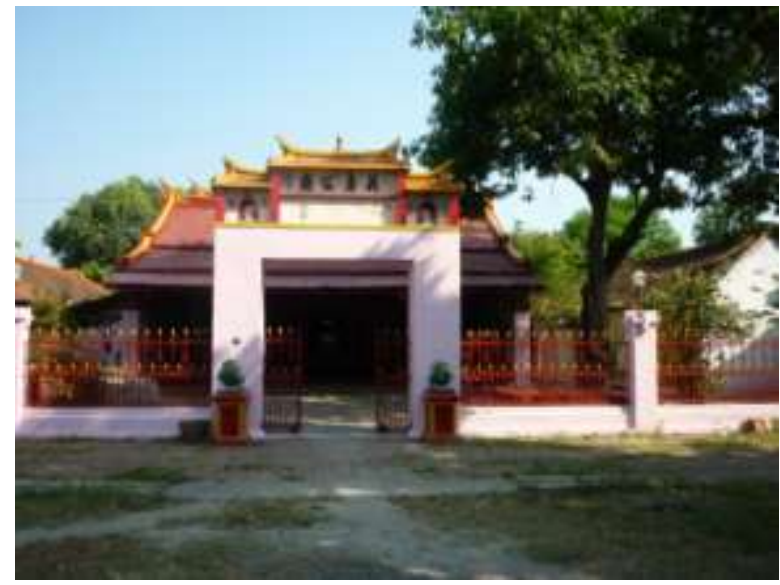

Figure 3 The Gie Yong Bio Temple, Babagan

The stories about their heroism are handed over through generations. Today's young generation in Lasem respect and admire their heroism. They understand that the solidarity of these three prominent figures is instrumental in uniting the Javanese and the Chinese in Lasem to fight against the Dutch. Lasem was safe from conflicts instigated by the Dutch due to the strong bonds between the Chinese and the Javanese. The Gie Yong Bio Temple in Babagan stands out as a monument symbolizing closeness and brotherhood of Lasem people. Until now, the acculturation, assimilation, and interethnic marriages continue. Interethnic marriages have existed for seven generations that it is difficult to separate Lasem people nowadays based on ethnicity alone (Aziz M. , 2014).

Historically speaking, buildings with Chinese architecture are influenced by Javanese coastal building design. Original Chinese architecture has been incorporated with Javanese architecture; thus, this creates a beautiful harmony. However, Handinoto (2015), pointed out that some parts of the Chinese architecture, a courtyard called si he yuan ( 四合院), is still well-preserved. . 


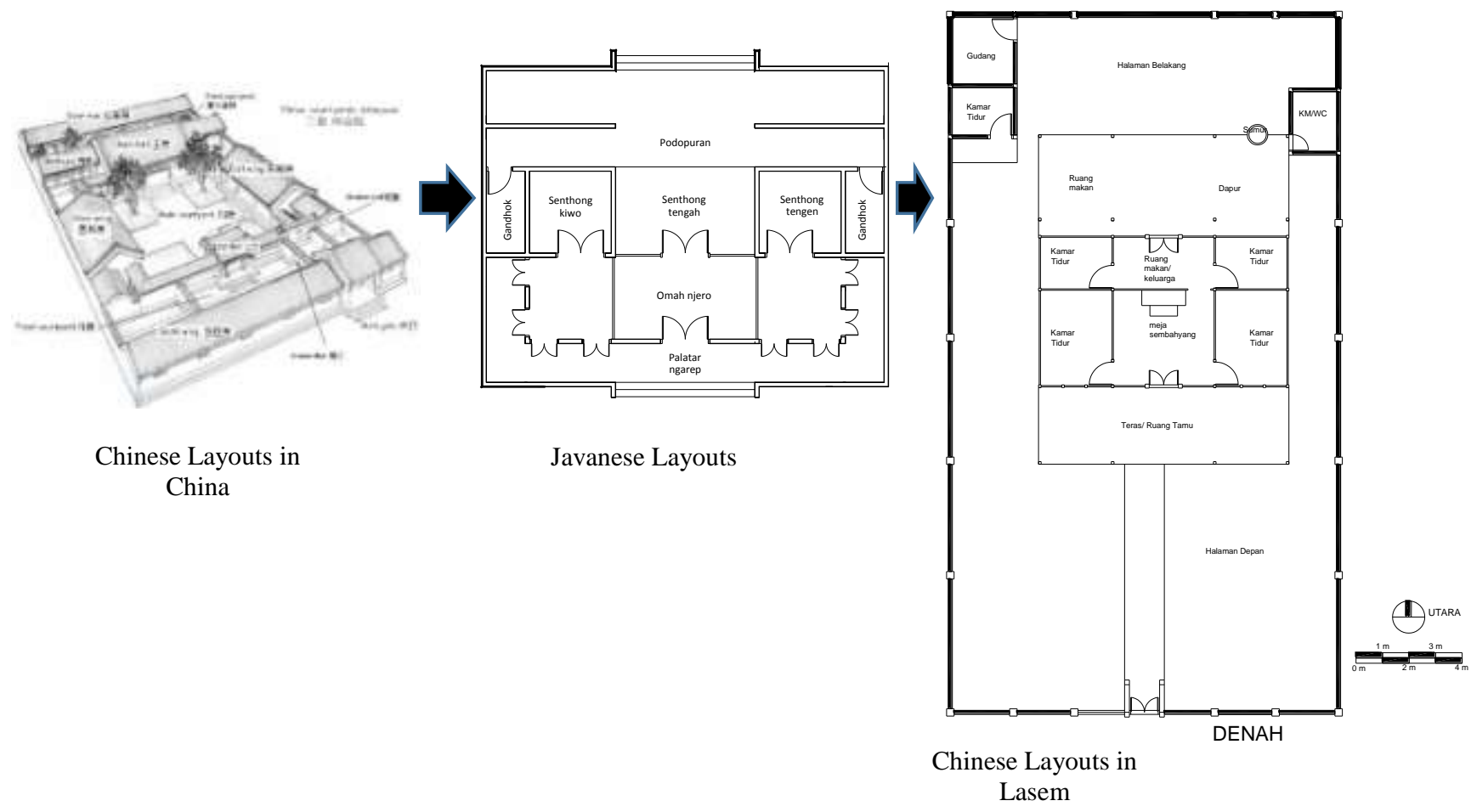

Figure 4. The manifestation of the Acculturation Process in Buildings in Lasem

As seen in Figure 4, the layout of Chinese building in Lasem appears to be similar with that of the Javanese due to the acculturation process of the people. Actually, Acculturation is a form of assimilation between two or more cultures which synergize to form a bridge between the characters of the two different cultures or multiple cultures (Eagleton, 2000).I

Chinese dwellings comprise several buildings. The main building has the same layout principle, but the building mass patterns still adhere to the Chinese architecture in China (Figure 5). The acculturation process is expressed through the design of the main buildings.
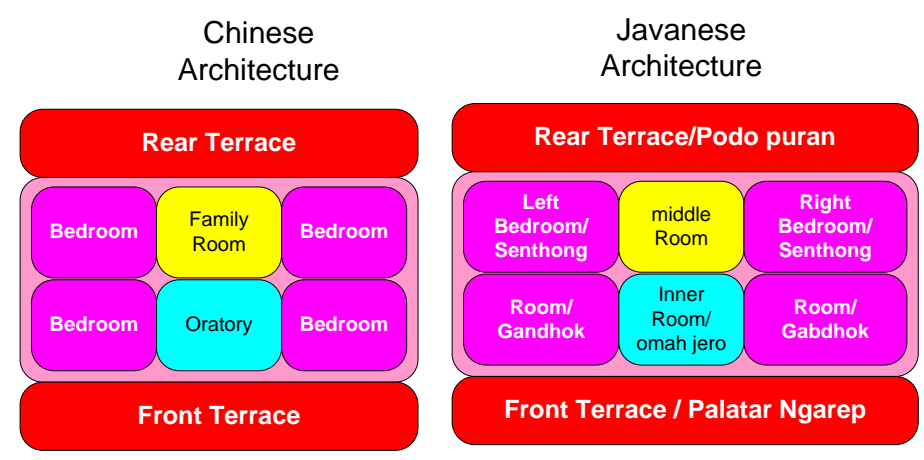

Figure 5. Similar Layouts of Chinese and Javanese houses in Lasem

In the buildings that the researchers observed, the houses with Chinese, Dutch, or Javanese architecture bear some similarities in terms of layouts. They are as follows (Figure 6). 


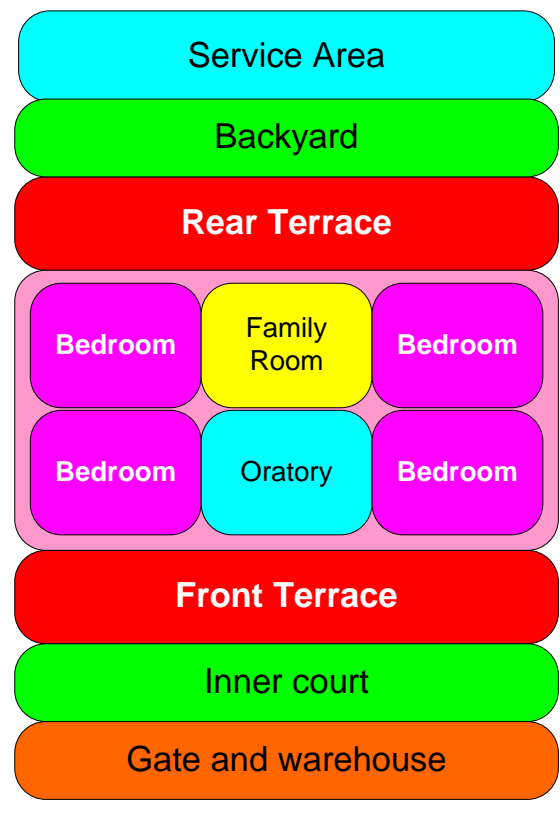

Figure 6. Layouts of Houses in Lasem

Houses whose owners are relatively friendly and outgoing often possess spacious terraces for them to socialize with people in the neighborhood. They usually gather at 6 to 8 in the morning before work to discuss topics related to tasks and responsibilities in the workplace, or perhaps after office hours instead, that is at 6 to 8 in the evening.

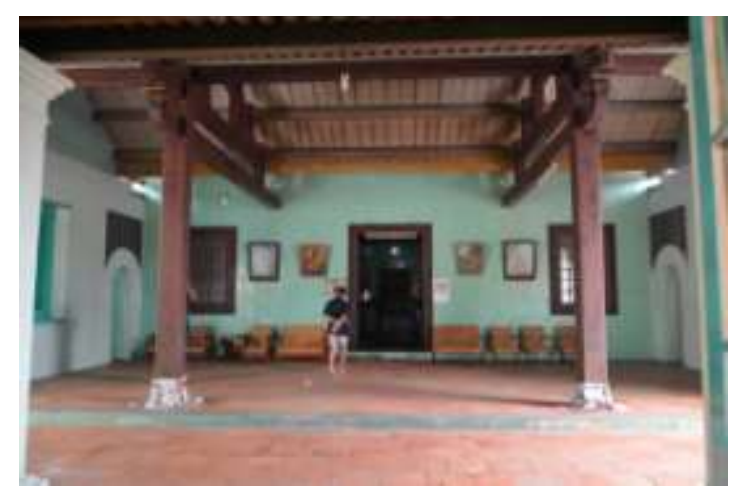

Figure 7 A terrace to facilitate people's gathering

A spacious terrace could also function as an open area for gathering, interacting, and discussing problems within the society. Interethnic assimilation across ethnicity takes place in the terrace. It is also reflected in Javanese gamelan instruments in these Chinese houses.

Another manifestation of acculturation process is the existence of Regol in front of buildings. Regol is a structure commonly found in Javanese building. Often used as an entrance gate, this structure is incorporated into the Chinese houses. There is an elongated structure in front of the house and it usually functions as a warehouse. 


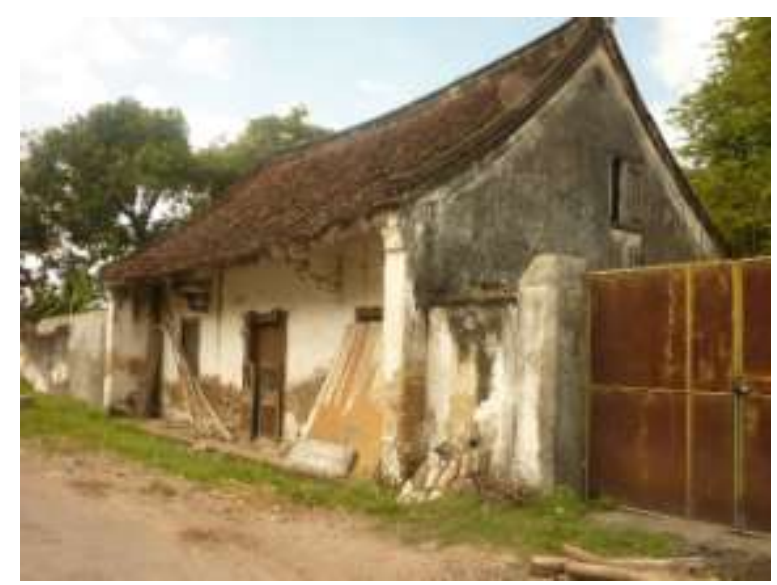

Figure 8. The Early Entrance Gate of Chinese Buildings

Source: Personal archive

In addition, the spacious front area of the house is designed for Regol, just like the one in Javanese houses, as the entrance gate. Here the constructed Regol conforms to Chinese architecture as does the main building. Regol is a product of mixing of Javanese and Chinese architecture.
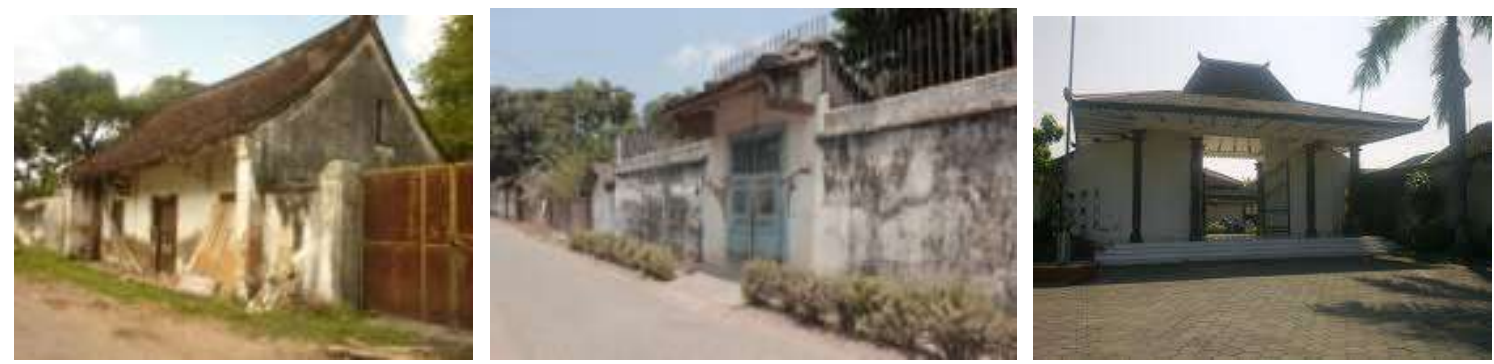

Figure 9. Regol as the entrance gate of Chinese and Javanese-oriented architecture

Source: Personal archive Document

In many Chinese buildings, there are consoles known as tou-kung ( 斗拱 ). These consoles are the icon of the city of Lasem. They are found not only in buildings with Chinese architecture, but also in buildings with Javanese architecture.
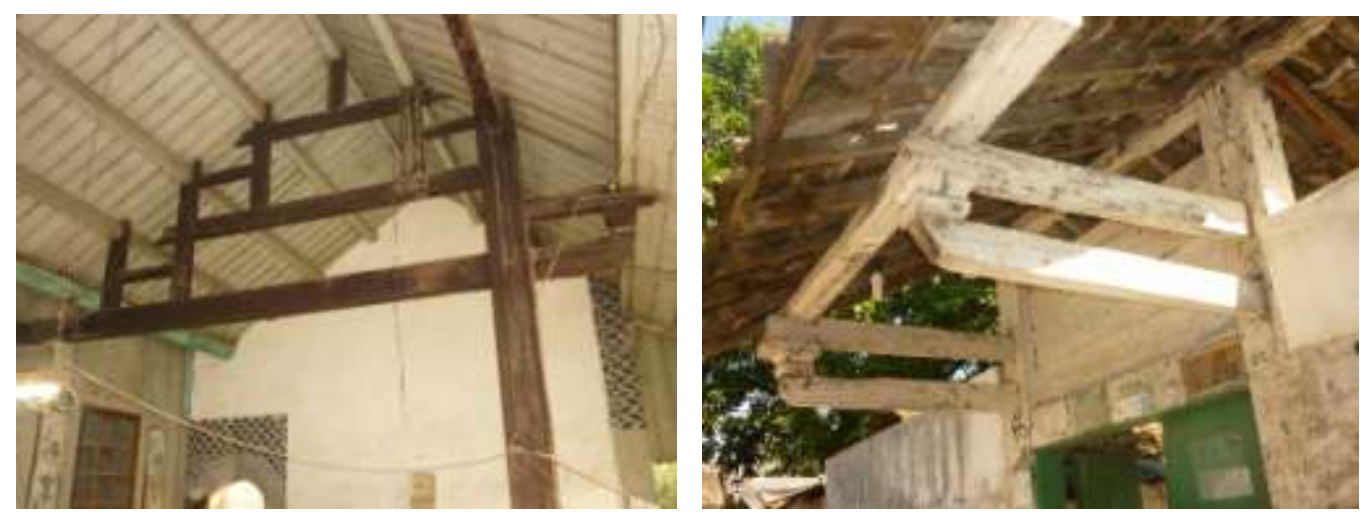

Figure 10. Tou-kung ( 斗拱 ) console on Chinese and Javanese houses

Source: Personal archive

\section{ACKNOWLEGEMENT}

Our greatest gratitude is directed towards the Directorate General of Higher Education for funding this research through fundamental research grants for our study entitled "The Study of Layouts and Building Systems of Chinese Architecture in Pecinan Lasem". 


\section{CONCLUSIONS AND SUGGESTIONS}

The course of history in the city of Lasem and the acculturation process between the Chinese and the Javanese have made the local citizen of Lasem more aware of the importance of maintaining social harmony and dampening conflicts to enhance the quality of life either socially or economically. It doesn't necessarily mean that conflicts, provocations, or misunderstandings among its people have never occured at all, but Lasem people can anticipate and resolve all sorts of conflicts in a more satisfying manner. They understand that they will be at a disadvantaged position if the social condition is not favorable.

Acculturation has been done by the community Lasem, not only in culture but also in the form of architecture, spatial patterns and details of buildings. This acculturation eliminate the distinctions between the Chinese community and Java, an easy-going horizontal conflicts. Acculturation also produces the typical rich diversity of architecture in the city Lasem

Social harmony in the society allows acculturation and assimilation to take place peacefully and is reflected through not only social life of Lasem citizens but also architectural designs. Acculturation and assimilation between the Chinese and the Javanese have influenced the space layout and the details of the buildings in Lasem and created newly designed and unique forms of architecture

\section{REFERENCES}

[1] Widodo, S.T., Interethnic Acculturation in Java: The Names of Chinese People in Lasem on the North Coast of Java, Asian Journal of Social Sciences \& Humanities Vol. 4 no.4, pp 8-15, November 2015

[1] Rizali, N. \& Bani Sudardi, Social Relation Between Javanese And Chinese Community In Batik Processing In Lasem Csentral Java, Journal of Education and Social Sciences, Vol. 5, issue 2, (October), pp 166-169, 2015

[2] Aziz, M., Lasem Kota Tiongkok kecil, Interaksi Tionghoa, Arab dan Jawa dalam silang budaya pesisiran (Lasem as a small Chinese town, Interaction of Chinese, Arabic and Java in a cross coastal culture), Penerbit Ombak, Yogyakarta, 2014

[2] Eagleton, T.. The idea of culture. Malden, MA: Blackwell Publisher Ltd. 2000

[2] Handinoto, Lasem, Kota Tua Bernuansa Cina di Jawa Tengah (Lasem, an Old Town with Chinese Nuance in Central Java), Penerbit Ombak, Yogyakarta, 2015

[2] Pratiwo, Arsitektur Tradisional Tionghoa dan Perkembangan Kota (Chinese Traditional Architecture and City Developments), Penerbit Ombak, Yogyakarta, 2010

[2] Rahab, M. Ed. Lasem; Sejarah Panjang Toleransi (Lasem, a Long History of Tolerance), Komunitas Rumah Buku Lasem, CV. Elzam Berkah Utama, Lasem, 2014

[2] Suryadinata, L., Dilema Minoritas Tionghoa (Dilemma of Chinese Minority), PT Grafiti Pers, Jakarta, 1984

[2] Tan Ta Sen, Cheng Ho, Penyebaran Islam dari China ke Nusantara (Cheng Ho, spread of Islam from China to the archipelago), PT Kompas Media Nusantara, Jakarta, 2010

[2] Vlekke, Bernard H.M., Nusantara: A History of Indonesia, N.V. Vitgeverij W. van Hoeve-S. Gravenhage, Brussel, 1959. 